\title{
Growth and Molecular Expression of Okra Seeds Interacted with Fourteen Mango Cultivars in Mixed Cropping System
}

\author{
Ream I. Marzouk ${ }^{1}$, Salama M. El-Darier ${ }^{1}$, Mona E. Mabrouk ${ }^{2} \&$ Kholod A. Khattab $^{2}$ \\ ${ }^{1}$ Botany and Microbiology Department, Faculty of Science, Alexandria University, Alexandria, Egypt \\ ${ }^{2}$ Botany and Microbiology Department, Faculty of Science, Damanhour University, Damanhour, Egypt \\ Correspondence: Kholod A. Khattab, Botany and Microbiology Department, Faculty of Science, Damanhour \\ University, Damanhour, Egypt. E-mail: kholodkhatab26@yahoo.com
}

Received: May 24, $2017 \quad$ Accepted: July 4, $2017 \quad$ Online Published: July 15, 2017

doi:10.5539/jas.v9n8p193 URL: https://doi.org/10.5539/jas.v9n8p193

\begin{abstract}
The present study was accomplished to study the effect of fourteen cultivars (Keitt, Ewais, White Succari, Tommy Atkins, Fajri Klan, Zebda, Alphonso, Sedeek, Naomi, Mesk, Baladi Dabsha, Baladi Arnaba, Cobania and Totapuri) of Mangifera indica L. leaves aqueous extracts (MILAE) on germination and some growth parameters as well as seedling protein profile of Hibiscus esculentus L. (okra seeds) in mixed cropping system. The study was extented to characterize and discriminate among the aforementioned cultivars. The allelopathic potential of fourteen cultivars of $M$. indica leaves aqueous extracts (MILAE) on germination efficiency and growth parameters of H. esculantus L. seeds (as a recipient bioassay material) was completely studied. Hypocotyl length (HL) was more sensitive than radicle length (RL) for all studied cultivars. At the all concentrations level, Mesk cultivar exerted the highest allelopathic effect, while Totapuri cultivar showed the lowest one on the germination percentage (GP), inhibition percentage (IP), the time to get $50 \%$ germination $\left(\mathrm{T}_{50}\right)$, mean germination time (MGT), germination energy (GE), seed germination index (SGI), emergence percentage (EP), mean emergence time (MET), seedling emergence index (EI), seedling vigour index (SVI), hypocotyl (HL) and radicle (RL) lengths, seedling fresh (SFW) and dry (SDW) weights.

Seedling protein electrophoresis data revealed that Tommy Atkins cultivar attained the minimum values for both the number of bands and the percentage of polymorphism, 6 bands and $27 \%$, respectively. On the other hand, the maximum values were achieved from both Naomi and Totapuri cultivars, 11 bands and $51 \%$. Reversibly, the genomic template stability (GTS \%) oscillated from 32\% in Cobania cultivar to $64 \%$ in specimen Tommy Atkins cultivar. The resulted dendrograms by using allelopathic and molecular data as well as seedling protein electophoresis ascertains three aggregations. The first assembly includes Sedeek, Naomi and Mesk cultivars. The second gathers Keitt and Ewais cultivars. While, the third clusters Fajri Klan, Zebda and Alphonso cultivars.
\end{abstract}

Keywords: allelochemicals, Hibiscus esculentus, Mangifera indica, polycropping practices, seedling protein electrophoresis

\section{Introduction}

Nowadays, there is a large move from monocropping to polycropping practices, in almost of the agricultural ecosystems along the world. One should be aware by the chemical interfering between the mixed crops in order to avoid undesirable potential effects of one crop on the other. El-Kenany et al. (2014) assessed the probable effects of Nigella sativa $\mathrm{L}$. seeds on the germination and growth alongside nutrient, metabolite and pigment content of Lupinus termis L. in mixed cropping system of the two crops. Multiple cropping is common practice in subtropical and tropical regions (Young et al., 1989; El-Kenany et al., 2014). Because there is a large move from mono-cropping to multiple cropping practices, one should be aware by the chemical interfering between the mixed crops in order to avoid undesirable potential effects of some crop on the others. A little is known about the allelopathic interaction of intercropped plants in mixed farming systems.

Mango (Mangifera indica L.), member of the cashew family (Anacardiaceae) is one of the most important and widely cultivated fruits of the tropical world. Mango attains high intraspecific diversity with about 1000-1600 cultivars in worldwide, of which 350 cultivars are in commercial production and the rest are limited to mixed orchards or home gardens (Bally, 2006; Aiyelaagbe \& Osamudiamen, 2009). Mango production is concentrated 
in El-Sharkia, El-Ismailia, El-Giza, EL-Fayoum and El-Behera (Nubariya) governorates (Abourayya et al., 2012). The lack of systematic approach in naming of mango cultivars in the past has resulted in a great confusion in their nomenclature due to many synonyms and duplication of names in the absence of any rules governing nomenclature (Kumar et al., 2013; Mansour et al., 2014).

Allelopathy is a physiological phenomenon with ecological implications and considered as an applicable technique in ecology (Reigosa et al., 2006). It is direct and indirect plant interactions mediated by allelochemicals (Cheema et al., 2013). An organism produces one or more biochemical (allelochemicals) influence the growth, survival and reproduction of other organisms. It also involves chemical interactions at all levels of complexity, from microorganisms to higher plants (Rice, 1974). When plants are exposed to allelochemicals, their growth and development are highly affected (Putnam \& Duke, 1978; Niakan et al., 2008). Allelochemicals significantly interfered with the protein expression of the recipient species. This interference took place either by induction or repression of the protein bands. The relatively high frequency of disappearance of bands may reveal that the survival of the individuals was greatly affected by allelochemicals (El-Khawas and Shehata, 2005; Cenkci et al., 2010; Sunar et al., 2013).

Allelopathic potential consider as a differential marker among cultivars, varities and growth forms (El-Darier et al., 2014). The differential allelopathic potential of cultivars was positively correlated with the contents of total phenolic acids (Labbafi et al., 2010; Bertholdsson, 2012). El-Darier et al. (2015) indicated that the phytochemical screening of fourteen mango cultivars (Keitt, Ewais, White Succari, Tommy Atkins, Fajri Kalan, Zebda, Alphonso, Sedeek, Naomi, Mesk, Baladi Dabsha, Baladi Arnaba, Cobania and Totapuri) was a successful tool to discriminate among them. In addation, the variation in phenolics, flavonoids and mangiferin were highly specific for these cultivars.

Seedling storage proteins are powerful tool for the detection of the genetic diversity and also considered as reliable technology because these are highly independent on environmental fluctuations (Javid et al., 2004; Iqbal et al., 2005; Netra \& Prasad, 2007; Sadia et al., 2009). Seedling storage protein profiling can be employed for various purposes, such as varietal and cultivar identification (El-Khawas \& Shehata, 2005), biosystematics analysis, determination of phylogenetic relationship among different species and generation of related information to complement evaluation (Sammour, 1991; Isemura et al., 2001; Ghafoor et al., 2002).

The main objective of the present study was to demonstrate and verify the interfere of allelochemicals liberated from young leaves of fourteen mango cultivars with germination efficiency and growth parameters as well as seedling protein profile of okra in mixed cropping system. The study was extented to characterize and discriminate among the aforementioned cultivars.

\section{Materials and Methods}

\subsection{Collection of Specimens}

Leaves of fourteen cultivars of M. indica L. were collected from El-Sharkia governorate (about $235 \mathrm{Km}$ east of Alexandria governorate). The cultivars were collected from two sites; El-salihiyyah Al-jadidah (50 Km from Al-Zakazik city) and El-sanagra village, Abu Hammad (15 Km from Al-Zakazik city). Nine cultivars were obtained from the first site, while five cultivars were gathered from the later site.

\subsection{Preparation of M. indica Leaves Aqueous Extract (MILAE)}

The collected leaves of the studied fourteen mango cultivars were washed and dried in an electric oven at $45^{\circ} \mathrm{C}$ then ground to a fine powder. One-hundred $\mathrm{ml}$ of sterile deionized water were added to $1,2,4$ and $8 \mathrm{~g}$ and the mixture was shaken and left for $48 \mathrm{~h}$ at refrigerator to $1,2,4$ and $8 \%$ beside the control (distilled water). The procedures were performed according to El-Rokiek et al. (2010) and Algandaby et al. (2014).

\subsection{Germination Bioassay}

Petri-dish experiment was applied to investigate the potential allelopathic effects of $M$. indica leaves aqueous extract (MILAE) of fourteen different cultivars on germination percentage (GP), emergence percentage (EP), mean emergence time (MET) and seedling vigour index (SVI), hypocotyl (HL) and radicle (RL) lengths, seedling fresh (SFW) and dry (SDW) weights. Also the experiment will be extended to assess the probable allelopathic interference between okra and different mango cultivars in mixed culture practices.

To accomplish this experiment, 20 seeds of $H$. esculentus L. (okra) (recipient species) were arranged in 9-cm diameter Petri-dishes on two discs of whatman No. 1 filter paper under normal laboratory conditions. Ten $\mathrm{ml}$ of MILAE (1, 2, 4 and 8\%) or distilled water as control were added daily to three replicates in a randomized complete block design. Half of the extract was used to moisten the bottom filter paper receiving the seeds while 
the remaining half was applied after covering seeds with filter paper and Petri dishes were covered with lid. Petri-dishes were placed at room temperature, with day temperature ranging $25-30{ }^{\circ} \mathrm{C}$ and night temperature ranging $20-25{ }^{\circ} \mathrm{C}$. The lid of Petri dish and the upper filter paper were removed just at initiation of seed germination and seedlings emergence. Seeds were considered to be germinated when their radicle was nearly 2 $\mathrm{mm}$, while seedlings were assessed as emerged when the cotyledons had unfolded above the surface and hypocotyl length was nearly $2 \mathrm{~mm}$. this procedure was described by Abdul Khaliq et al. (2012).

Before sowing, the seeds were immersed in 2\% CHLOREX for 2 minutes then rinsed four times with distilled water. Finally, the seeds were soaked in aerated distilled water for 24 hours. GP, EP, HL and RL were recorded daily for successive sixteen days according to AOSA (1990). After sixteen days, the homogenous seedling were carefully collected from each treatment, washed with tap water and then by distilled water, gently blotted with filter paper. Fresh weight of seedlings was determined and then seedlings were dried at $65^{\circ} \mathrm{C}$ till constant weight to determine the dry weight.

\subsection{Calculations and Data Analyses}

(1) Mean Emergence Time (MET)

Mean emergence time (MET) was calculated according to the equation of Ellis and Roberts (1981).

$$
\text { MET }=\Sigma \text { Number of emerged seedlings/Day of counting }
$$

(2) Seedling Vigour Index (SVI)

Seedling vigour index (SVI) was calculated according to the equation of Islam et al. (2009) and Elouaer and Hannachi (2012).

$$
\mathrm{SVI}=[\text { Seedling length }(\mathrm{cm}) \times \text { Germination percentage }] / 100
$$

\subsection{Data Analysis and Computer Programs}

Data were subjected to standard analysis of variance (ANOVA) using COSTAT 2.00 statistical analysis software manufactured by Cohort software company (Zar, 1984). In addition, data were subjected to numerical analysis using PAST program for mixed data set (Hammer et al., 2001). The agglomerative cluster analysis was conducted by using "Euclidean" coefficient (Hammer et al., 2005) through the Unweighed Pair Group Method using Arithmetic averages (average linkage, UPGMA) method of sorting to estimate the relationships among the fourteen cultivars.

Euclidean Distance Coefficient:

$$
\text { Euclidean }_{\mathrm{jk}}=\sum_{\mathrm{i}=1}^{\mathrm{S}}\left(\mathrm{X}_{\mathrm{ij}}-\mathrm{X}_{\mathrm{ik}}\right)^{2}
$$

Where,

$\mathrm{S}=$ number of species being compared, $\mathrm{X}_{\mathrm{ij}}=$ frequency of species $\mathrm{j}$ in sample $\mathrm{i}\left(\mathrm{i}=\right.$ sample number 1,2 , etc), $\mathrm{X}_{\mathrm{ik}}$ $=$ frequency of species $\mathrm{k}$ in sample $\mathrm{i}(\mathrm{i}=$ sample number 1,2 , etc $)$.

\subsection{Growth Experiment}

Growth experiment was performed to test the allelopathic effect of high concentration level (8\%) of $M$. indica leaves aqueous extract (MILAE) of the studied cultivars with sandy clay soil on seedling protein electrophoresis as molecular marker.

The soil samples were finally sterilized at $\left(90^{\circ} \mathrm{C}\right.$ for $\left.48 \mathrm{~h}\right)$ to remove any microorganisms and weed seeds. Twenty seeds of $H$. esculentus were sown in plastic pots $(16 \mathrm{~cm}$ in diameter) with about $1500 \mathrm{~g}$ of sandy clay soil. Ten $\mathrm{ml}$ of MILAE (8\%) and distilled water as control were added daily to three replicates in a randomized complete block design. Before sowing, the seeds were immersed in 2\% CHLOREX for 2 minutes then rinsed four times with distilled water. Finally, the seeds were soaked in aerated distilled water for 24 hours. The experiment was performed under normal laboratory conditions $\left(20 \pm 2{ }^{\circ} \mathrm{C}\right.$ temperature, $75 \pm 2 \%$ relative humidity, and $14 / 10 \mathrm{~h} /$ dark photoperiod).

After twenty one days, the homogenous seedling were carefully collected then washed with tap water to remove the adhering soil particles, and then, by distilled water, gently blotted with filter paper. Shoot system prepared and concealed with foil paper then put in ice and used for seedling protein electrophoresis experiment. 


\subsection{Seedling Protein Electrophoresis}

For assessing the allelopathic effect of the fourteen cultivars of $M$. indica leaves aqueous extract (MILAE) at 8\% concentration, on the protein content of $H$. esculentus seedling, sodium dodecyl sulphate polyacrylamide gel electrophoresis (SDS-PAGE) was carried out according to Laemmli (1970).

\subsection{Data Analysis and Computer Programs}

The bands produced by each sample were counted and the percentage of polymorphism was determined according to the following equation:

The percentage of polymorphism $=[(\Sigma$ Bands for each sample $/ \Sigma$ Bands for all samples $] \times 100$

Genomic template stability (GTS \%) was calculated as the following:

$$
\text { GTS } \%=(1-\mathrm{a} / \mathrm{n}) \times 100
$$

Where, a: average number of polymorphic bands detected in each treated sample, (polymorphism include appearance of new bands and disappearance normal bands), $\mathrm{n}$ : total number of bands (Cimino, 2006).

The different molecular weights were determined by means of UVP Doc-It ${ }^{\circ} L S$ image Analysis Software, and employed in the analysis by using PAST program (Hammer et al., 2001) to compute the genetic distances and generate the dendrogram. The agglomerative cluster analysis was conducted by using "Chord" coefficient (Hammer et al., 2005) through the Unweighed Pair Group Method using Arithmetic averages (average linkage, UPGMA) method of sorting.

Chord Coefficient:

$$
\text { Chord }_{\mathrm{jk}}=\sqrt{2-2 \frac{\sum_{\mathrm{i}=1}^{\mathrm{S}}\left(\mathrm{X}_{\mathrm{ij}} \mathrm{X}_{\mathrm{i} k}\right)}{\sqrt{\sum_{\mathrm{i}=1}^{\mathrm{S}} \mathrm{X}_{\mathrm{ij}}^{2} \sum_{\mathrm{i}=1}^{\mathrm{S}} \mathrm{X}_{\mathrm{ik}}^{2}}}}
$$

Where,

$\mathrm{S}=$ number of species being compared, $X_{\mathrm{ij}}=$ frequency of species $\mathrm{j}$ in sample $\mathrm{i}\left(\mathrm{i}=\right.$ sample number 1,2 , etc), $\mathrm{X}_{\mathrm{ik}}$ $=$ frequency of species $\mathrm{k}$ in sample $\mathrm{i}(\mathrm{i}=$ sample number 1,2 , etc $)$.

\section{Results}

\subsection{Germination Efficiency}

Data concerning the germination percentage (GP), emergence percentage (EP), mean emergence time (MET) and seedling vigour index (SVI) of H. esculentus $\mathrm{L}$. are illustrated Table 1. Petri-dish experiment demonstrated that the GP and EP of $H$. esculentus was significantly $(\mathrm{p} \leq 0.05)$ affected upon applying different concentration levels of fourteen cultivars of $M$. indica L. leaves aqueous extract (MILAE). Commonly, GP and EP decreased with the increase in MILAE concentration. At the end of the experiment (after sixteen days) GP and EP attended a value of about $100 \%$ at control level for all the fourteen studied cultivars. However, at the consequent concentrations $(1,2,4$ and $8 \%)$ the values were significantly decreased and prominent in EP relative to GP.

On contrarily to the last mentioned germination parameters (GP and EP), the value of the mean emergence time (MET), increased markedly as MILAE concentration increased, MET are illustrated and statistically represented in. This increase was statistically significant at $(p \leq 0.05)$ as evaluated by ANOVA test. At control level, the value of MET was 1 respectively for all studied cultivars. In MET the values ranged from a minimum in Totapuri cultivar and a maximum in Mesk cultivar. At 2\% MILAE concentration, values of MET ranged from a minimum in Totapuri cultivar and a maximum in Mesk cultivar. At 4\% MILAE concentration, values of MET ranged from a minimum in Totapuri cultivar and a maximum in Mesk cultivar. In MET a notable increase was attained along the higher MILAE concentration (8\%), in MET the values were increased in Mesk cultivar to a maximum values of about 11.1.

The values of seedling vigour (SVI) index, decreased distinctly as MILAE concentration increased. SVI was illustrated and statistically represented in Table 1 . This reduction was statistically significant at $(\mathrm{p} \leq 0.05)$ as evaluated by ANOVA test. At control level, while SVI attain a value of about 20 for all studied fourteen cultivars. At $(1,2,4$ and $8 \%$ ) MILAE concentration SVI conquered a value ranged from a minimum in Mesk cultivar to a maximum in Totapuri cultivar. 
Table 1. Variation in germination percentage (GP), emergence percentage (EP), mean emergence time (MET) and seedling vigour index (SVI) of Hibiscus esculentus L. seeds (sixteen days after sowing) as affected by different concentration levels (\%) of fourteen cultivars of Mangifera indica leaves aqueous extract (MILAE). Different letters within each column for each cultivar indicate a significant difference at $\mathrm{p}<0.05$ according to one way ANOVA test

\begin{tabular}{|c|c|c|c|c|c|c|c|c|c|c|c|c|c|c|c|}
\hline 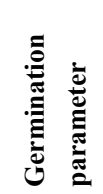 & 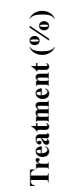 & 莺 & 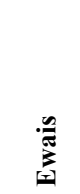 & 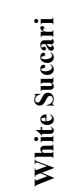 & 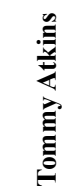 & 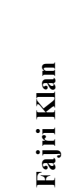 & $\begin{array}{l}\frac{\pi}{0} \\
\frac{0}{0} \\
\text { N }\end{array}$ & 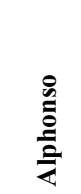 & $\frac{\check{E}}{\tilde{E}}$ & $\begin{array}{l}\tilde{\Xi} \\
\bar{z} \\
\tilde{z}\end{array}$ & $\frac{4}{\bar{a}}$ & 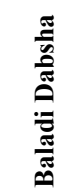 & 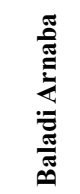 & 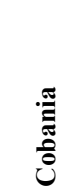 & 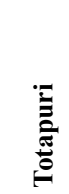 \\
\hline \multirow[t]{5}{*}{ GP } & $\mathrm{C}$ & $100^{\mathrm{a}}$ & $100^{\mathrm{a}}$ & $100^{\mathrm{a}}$ & $100^{\mathrm{a}}$ & $100^{\mathrm{a}}$ & $100^{\mathrm{a}}$ & $100^{\mathrm{a}}$ & $100^{\mathrm{a}}$ & $100^{\mathrm{a}}$ & $100^{\mathrm{a}}$ & $100^{\mathrm{a}}$ & $100^{\mathrm{a}}$ & $100^{\mathrm{a}}$ & $100^{\mathrm{a}}$ \\
\hline & 1 & $96^{\mathrm{b}}$ & $94^{\mathrm{b}}$ & $91^{\mathrm{b}}$ & $98^{\mathrm{b}}$ & $88^{\mathrm{b}}$ & $97^{\mathrm{b}}$ & $88^{\mathrm{b}}$ & $86^{\mathrm{b}}$ & $83^{\mathrm{b}}$ & $80^{\mathrm{b}}$ & $95^{\mathrm{b}}$ & $96^{\mathrm{b}}$ & $97^{\mathrm{b}}$ & $99^{\mathrm{b}}$ \\
\hline & 2 & $90^{\mathrm{c}}$ & $88^{\mathrm{c}}$ & $89^{\mathrm{c}}$ & $93^{\mathrm{c}}$ & $84^{\mathrm{c}}$ & $90^{\mathrm{c}}$ & $80^{\mathrm{c}}$ & $75^{\mathrm{c}}$ & $77^{\mathrm{c}}$ & $73^{\mathrm{c}}$ & $91^{\mathrm{b}}$ & $92^{\mathrm{c}}$ & $92^{\mathrm{c}}$ & $95^{\mathrm{c}}$ \\
\hline & 4 & $74^{\mathrm{d}}$ & $84^{\mathrm{d}}$ & $79^{\mathrm{c}}$ & $86^{\mathrm{d}}$ & $76^{\mathrm{d}}$ & $85^{\mathrm{d}}$ & $70^{\mathrm{d}}$ & $69^{\mathrm{d}}$ & $67^{\mathrm{d}}$ & $60^{\mathrm{d}}$ & $88^{\mathrm{c}}$ & $85^{\mathrm{d}}$ & $88^{\mathrm{d}}$ & $91^{\mathrm{d}}$ \\
\hline & 8 & $62^{\mathrm{e}}$ & $76^{\mathrm{e}}$ & $73^{d}$ & $77^{\mathrm{d}}$ & $69^{\mathrm{e}}$ & $77^{\mathrm{d}}$ & $65^{\mathrm{e}}$ & $60^{\mathrm{e}}$ & $63^{\mathrm{e}}$ & $50^{\mathrm{e}}$ & $80^{\mathrm{d}}$ & $78^{\mathrm{e}}$ & $83^{\mathrm{d}}$ & $86^{\mathrm{e}}$ \\
\hline \multirow[t]{5}{*}{ EP } & C & $100^{\mathrm{a}}$ & $100^{\mathrm{a}}$ & $100^{\mathrm{a}}$ & $100^{\mathrm{a}}$ & $100^{\mathrm{a}}$ & $100^{\mathrm{a}}$ & $100^{\mathrm{a}}$ & $100^{\mathrm{a}}$ & $100^{\mathrm{a}}$ & $100^{\mathrm{a}}$ & $100^{\mathrm{a}}$ & $100^{\mathrm{a}}$ & $100^{\mathrm{a}}$ & $100^{\mathrm{a}}$ \\
\hline & 1 & $65^{\mathrm{b}}$ & $70^{\mathrm{b}}$ & $76^{\mathrm{b}}$ & $80^{\mathrm{b}}$ & $69^{\mathrm{b}}$ & $79^{\mathrm{b}}$ & $71^{\mathrm{b}}$ & $55^{\mathrm{b}}$ & $57^{\mathrm{b}}$ & $45^{\mathrm{b}}$ & $68^{\mathrm{b}}$ & $80^{\mathrm{b}}$ & $82^{\mathrm{b}}$ & $85^{\mathrm{b}}$ \\
\hline & 2 & $55^{\mathrm{c}}$ & $63^{\mathrm{c}}$ & $65^{\mathrm{c}}$ & $69^{\mathrm{c}}$ & $57^{\mathrm{c}}$ & $66^{\mathrm{c}}$ & $56^{\mathrm{c}}$ & $40^{\mathrm{c}}$ & $39^{\mathrm{c}}$ & $36^{\mathrm{c}}$ & $54^{\mathrm{c}}$ & $66^{\mathrm{c}}$ & $70^{\mathrm{c}}$ & $74^{\mathrm{c}}$ \\
\hline & 4 & $38^{\mathrm{d}}$ & $49^{\mathrm{d}}$ & $50^{\mathrm{d}}$ & $55^{\mathrm{d}}$ & $43^{\mathrm{d}}$ & $45^{\mathrm{d}}$ & $31^{\mathrm{d}}$ & $33^{\mathrm{d}}$ & $30^{\mathrm{d}}$ & $25^{\mathrm{d}}$ & $39^{\mathrm{d}}$ & $52^{\mathrm{d}}$ & $60^{\mathrm{d}}$ & $63^{\mathrm{d}}$ \\
\hline & 8 & $25^{\mathrm{e}}$ & $32^{\mathrm{e}}$ & $34^{\mathrm{e}}$ & $39^{\mathrm{e}}$ & $28^{\mathrm{e}}$ & $30^{\mathrm{e}}$ & $23^{\mathrm{e}}$ & $20^{\mathrm{e}}$ & $18^{\mathrm{e}}$ & $15^{\mathrm{e}}$ & $22^{\mathrm{e}}$ & $37^{\mathrm{e}}$ & $40^{\mathrm{e}}$ & $45^{\mathrm{e}}$ \\
\hline \multirow[t]{5}{*}{ MET } & C & $1.0^{\mathrm{a}}$ & $1.0^{\mathrm{a}}$ & $1.0^{\mathrm{a}}$ & $1.0^{\mathrm{a}}$ & $1.0^{\mathrm{a}}$ & $1.0^{\mathrm{a}}$ & $1.0^{\mathrm{a}}$ & $1.0^{\mathrm{a}}$ & $1.0^{\mathrm{a}}$ & $1.0^{\mathrm{a}}$ & $1.0^{\mathrm{a}}$ & $1.0^{\mathrm{a}}$ & $1.0^{\mathrm{a}}$ & $1.0^{\mathrm{a}}$ \\
\hline & 1 & $1.6^{\mathrm{b}}$ & $1.4^{\mathrm{b}}$ & $1.2^{\mathrm{b}}$ & $1.2^{\mathrm{b}}$ & $1.4^{\mathrm{b}}$ & $1.2^{\mathrm{b}}$ & $1.4^{\mathrm{b}}$ & $1.7^{\mathrm{b}}$ & $1.6^{\mathrm{b}}$ & $2.1^{\mathrm{b}}$ & $1.4^{\mathrm{b}}$ & $1.2^{\mathrm{b}}$ & $1.1^{\mathrm{b}}$ & $1.1^{\mathrm{b}}$ \\
\hline & 2 & 2.0 & $1.6^{\mathrm{c}}$ & $1.7^{\mathrm{c}}$ & $1.5^{\mathrm{c}}$ & $1.8^{\mathrm{c}}$ & $1.7^{\mathrm{c}}$ & $2.2^{\mathrm{c}}$ & $2.9^{\mathrm{c}}$ & $3.0^{\mathrm{c}}$ & $3.2^{\mathrm{c}}$ & $2.1^{\mathrm{c}}$ & $1.4^{\mathrm{c}}$ & $1.3^{\mathrm{c}}$ & $1.2^{\mathrm{c}}$ \\
\hline & 4 & $3.4^{\mathrm{d}}$ & $2.3^{\mathrm{d}}$ & $2.2^{\mathrm{d}}$ & $2.0^{\mathrm{d}}$ & $2.3^{\mathrm{d}}$ & $2.6^{\mathrm{d}}$ & $4.2^{\mathrm{d}}$ & $3.7^{\mathrm{d}}$ & $5.0^{\mathrm{d}}$ & $6.2^{\mathrm{d}}$ & $3.1^{\mathrm{d}}$ & $2.4^{\mathrm{d}}$ & $2.1^{\mathrm{d}}$ & $1.9^{\mathrm{d}}$ \\
\hline & 8 & $5.5^{\mathrm{e}}$ & $3.5^{\mathrm{e}}$ & $3.8^{\mathrm{e}}$ & $3.4^{\mathrm{e}}$ & $5.0^{\mathrm{e}}$ & $4.5^{\mathrm{e}}$ & $6.6^{\mathrm{e}}$ & $7.7^{\mathrm{e}}$ & $9.0^{\mathrm{e}}$ & $9.1^{\mathrm{e}}$ & $6.1^{\mathrm{e}}$ & $3.7^{\mathrm{e}}$ & $2.9^{\mathrm{e}}$ & $2.6^{\mathrm{e}}$ \\
\hline \multirow[t]{5}{*}{ SVI } & C & $20.5^{\mathrm{a}}$ & $20.5^{\mathrm{a}}$ & $20.5^{\mathrm{a}}$ & $20.5^{\mathrm{a}}$ & $20.5^{a}$ & $20.5^{\mathrm{a}}$ & $20.5^{\mathrm{a}}$ & $20.5^{\mathrm{a}}$ & $20.5^{\mathrm{a}}$ & $20.5^{\mathrm{a}}$ & $20.5^{\mathrm{a}}$ & $20.5^{\mathrm{a}}$ & $20.5^{\mathrm{a}}$ & $20.5^{\mathrm{a}}$ \\
\hline & 1 & $10.1^{\mathrm{b}}$ & $11.9^{\mathrm{b}}$ & $9.9^{b}$ & $13.3^{b}$ & $8.0^{\mathrm{b}}$ & $10.7^{\mathrm{b}}$ & $7.5^{\mathrm{b}}$ & $6.6^{\mathrm{b}}$ & $5.9^{\mathrm{b}}$ & $5.4^{\mathrm{b}}$ & $8.7^{\mathrm{b}}$ & $10.1^{\mathrm{b}}$ & $11.6^{\mathrm{b}}$ & $13.9^{b}$ \\
\hline & 2 & $8.6^{\mathrm{c}}$ & $10.2^{\mathrm{c}}$ & $9.1^{\mathrm{c}}$ & $10.4^{\mathrm{c}}$ & $6.5^{\mathrm{c}}$ & $8.6^{\mathrm{c}}$ & $6.5^{\mathrm{c}}$ & $5.2^{\mathrm{c}}$ & $4.6^{\mathrm{c}}$ & $4.4^{\mathrm{c}}$ & $7.7^{\mathrm{c}}$ & $8.8^{\mathrm{c}}$ & $8.2^{\mathrm{c}}$ & $11.9^{\mathrm{c}}$ \\
\hline & 4 & $6.0^{\mathrm{d}}$ & $8.4^{\mathrm{d}}$ & $6.7^{\mathrm{d}}$ & $8.6^{\mathrm{d}}$ & $5.0^{\mathrm{d}}$ & $5.4^{\mathrm{d}}$ & $5.0^{\mathrm{d}}$ & $4.1^{\mathrm{d}}$ & $3.5^{\mathrm{d}}$ & $31.8^{\mathrm{d}}$ & $6.3^{\mathrm{d}}$ & $6.6^{\mathrm{d}}$ & $6.8^{\mathrm{d}}$ & $8.8^{\mathrm{d}}$ \\
\hline & 8 & $3.7^{\mathrm{e}}$ & $6.8^{\mathrm{e}}$ & $4.2^{\mathrm{e}}$ & $4.9^{\mathrm{e}}$ & $3.5^{\mathrm{e}}$ & $3.6^{\mathrm{e}}$ & $2.2^{\mathrm{e}}$ & $3.1^{\mathrm{e}}$ & $2.9^{\mathrm{e}}$ & $2.1^{\mathrm{e}}$ & $4.9^{\mathrm{e}}$ & $4.6^{\mathrm{e}}$ & $5.7^{\mathrm{e}}$ & $6.5^{\mathrm{e}}$ \\
\hline
\end{tabular}

\subsection{Hypocotyl (HL) and Radicle (RL) Lengths}

The allelopathic effect of MILAE concentration on hypocotyl (HL) and radicle lengths of okra are illustrated and represented as exponential regression in Figure 1. MILAE extract concentration levels have statistically reduced both hypocotyl (HL) and radicle lengths. The applied concentrations are significant at $p \leq 0.05$. Hypocotyl length of $H$. esculentus was more sensitive than radicle length as affected by different concentration levels of all studied cultivars of $M$. indica leaves aqueous extracts. Apparently, HL and RL decreased with the increase of MILAE concentration in all fourteen cultivars (negative exponential relationship) where $\mathrm{R}^{2}=0.9$. After sixteen days from sowing, HL and RL attended a gradual reduction at (control level, $1 \%, 2 \%, 4 \%$ and $8 \%$ ) for the fourteen studied cultivars. The values were significantly decreased and prominent in Mesk cultivar relative to Totapuri cultivar. 

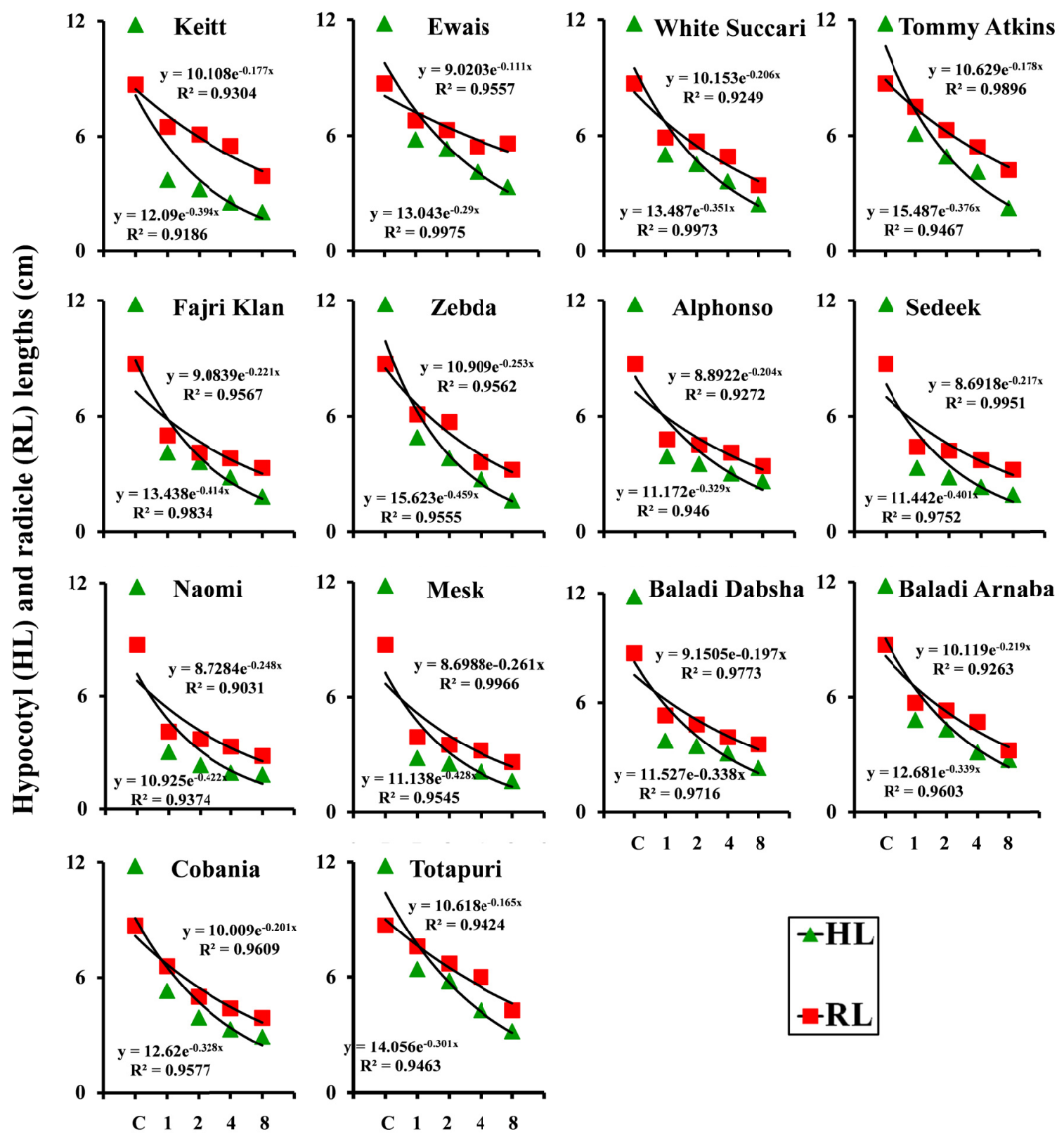

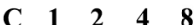

$\begin{array}{lllll}\text { C } & 1 & 2 & 4 & 8\end{array}$

\section{Concentration (\%)}

Figure 1. Exponential regression of hypocotyl (HL) and radicle (RL) lengths of Hibiscus esculentus seeds (sixteen days after sowing) as affected by different concentration levels (\%) of fourteen cultivars of Mangifera indica leaves aqueous extracts

\subsection{Fresh (SFW) and Dry (SDW) Weights}

The allelopathic effect of MILAE concentration on seedling fresh (SFW) and dry (SDW) weights of $H$. esculentus L. are illustrated and represented as exponential regression in Figure 2. MILAE extract concentration levels have statistically reduced SFW and SDW. The applied concentrations are significant at $p \leq 0.05$. Usually, SFW and SDW decreased with the increase of MILAE concentration for all studied cultivars (negative exponential relationship) where $\mathrm{R}^{2}=0.9$. SFW and SDW attended a gradual reduction at (control level, $1 \%, 2 \%$, $4 \%$ and $8 \%$ ) for the fourteen studied cultivars. The values were significantly decreased and prominent in Mesk cultivar relative to Totapuri cultivar. 


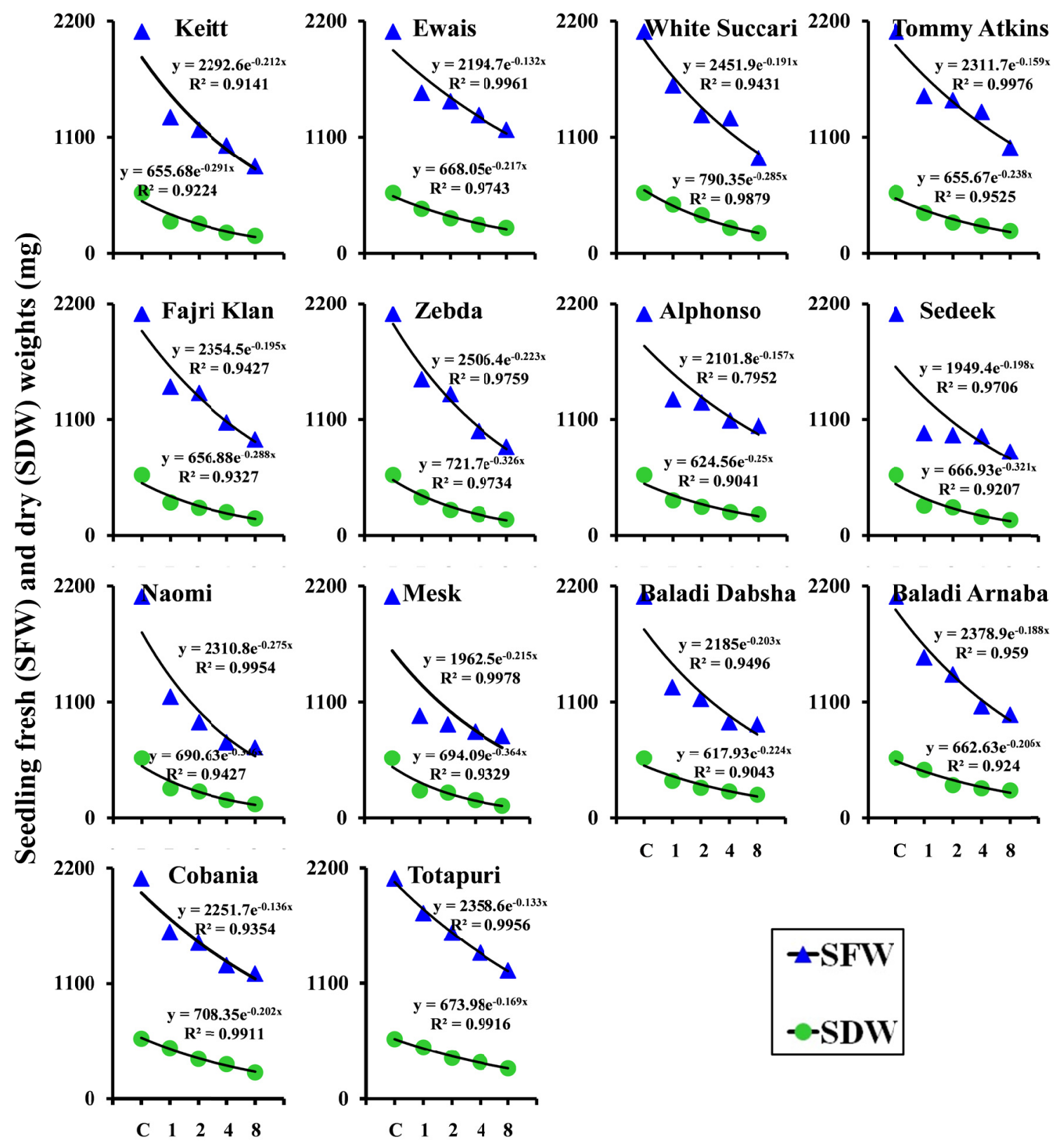

\section{Concentration (\%)}

Figure 2. Exponential regression of seedling fresh (SFW) and dry (SDW) weights of of Hibiscus esculentus seeds (sixteen days after sowing) as affected by different concentration levels (\%) of fourteen cultivars of Mangifera indica leaves aqueous extracts

The results obtained from the fourteen studied cultivars of mango are subjected to numerical analysis to discriminate among them. The use of the allelopathic characters emergence percentage (EP), mean emergence time (MET), seedling vigour index (SVI), hypocotyl (HL) and radicle (RL) lengths, fresh (SFW) and dry (SDW) weights provide a reliable dendrogram rather than using each character separately or collectively (germination and reduction characters). This is attributed to avoiding the logically correlated characters to be used in the numerical analysis. The dendrogram based on allelopathic characters discriminates studied cultivars into three aggregations. The first assembly includes Sedeek, Naomi and Mesk cultivars. The second gathers Keitt and Ewais cultivars. While, the third clusters Fajri Klan, Zebda and Alphonso cultivars (Figure 3). 


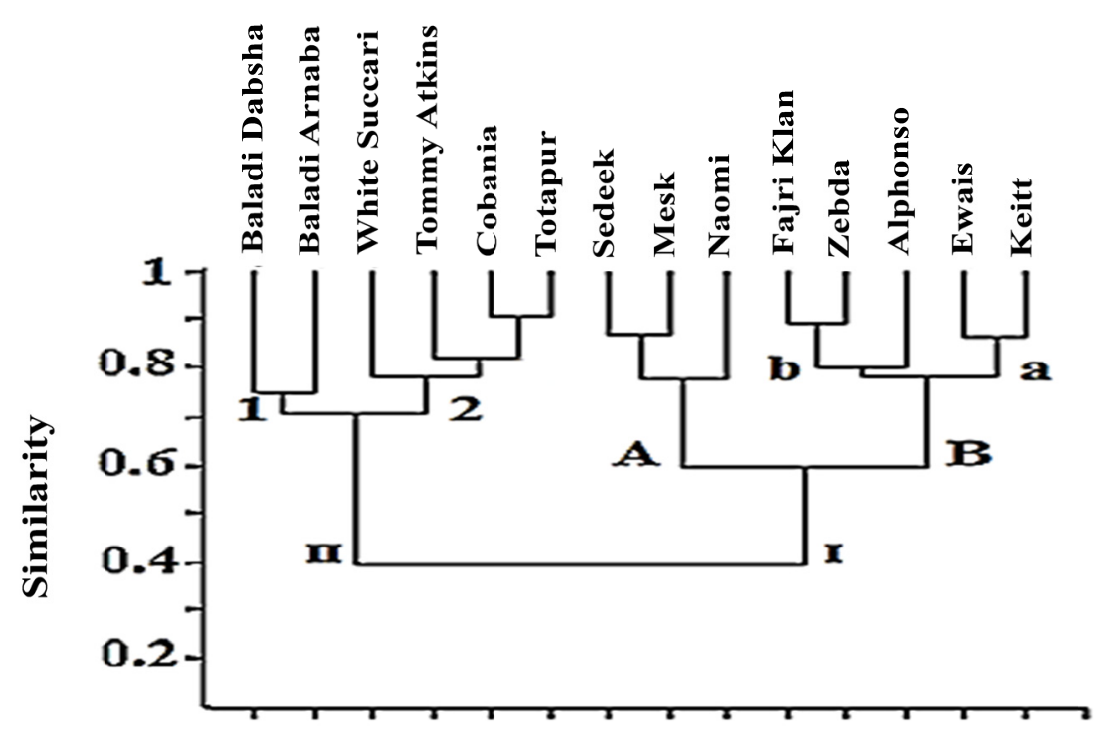

Figure 3. Dendrogram resulting from UPGMA method of sorting using the allelopathic effect of fourteen cultivars of Mangifera indica L. leaves aqueous extract under different concentration levels (Control, 1, 2, 4 and 8\%) on Hibiscus esculentus seeds

\subsection{Seedling Protein Electrophoresis}

The electrograms of the fourteen H. esculentus specimens, which were subjected to the allelopathic effects of the fourteen mango cultivars, are illustrated in Figure 4. However, the constructed dendrogram elucidated the relationships among them was declared in Figure 5. A total of 22 bands are produced without both common or specific bands. The specimen 4 (subjected to Tommy Atkins cultivar) attained the minimum values for both the number of bands and the percentage of polymorphism, 6 bands and $27 \%$, respectively. On the other hand, the maximum values were achieved from both specimens " 9 " and "14" (subjected to Naomi and Totapuri cultivars), 11 bands and $51 \%$ (Table 2). The studied specimens manifested the appearance and the disappearance of bands, as well as the alteration bands intensities. Both the appearance and disappearance of bands fluctuated from 8 to 15 bands in specimens "4" (subjected to Tommy Atkins cultivar) and "9" (subjected to Naomi cultivar), respectively. Reversibly, the genomic template stability (GTS \%) oscillated from $32 \%$ in specimen "11" (subjected to Cobania cultivar) to 64\% in specimen "4" (subjected to Tommy Atkins cultivar) (Table 3).

The constructed dendrogram based on seedling proteins divaricated at 0.15 similarity level, into two major groups "I" and "II". The major group "I" includes 5 specimens affective by cultivars; Keitt, Ewais, Fajri Klan, Zebda and Alphonso. Similarly, in the major group "II", the specimens subjected to Sedeek, Naomi and Mesk cultivars are clustered together as in the dendrogram based on allelopathic characters (Figure 5).

Table 2. Details of the seedling protein patterns for the study species Hibiscus esculentus L. affected by $8 \%$ concentration of fourteen cultivars of Mangifera indica L. leaves aqueous extract

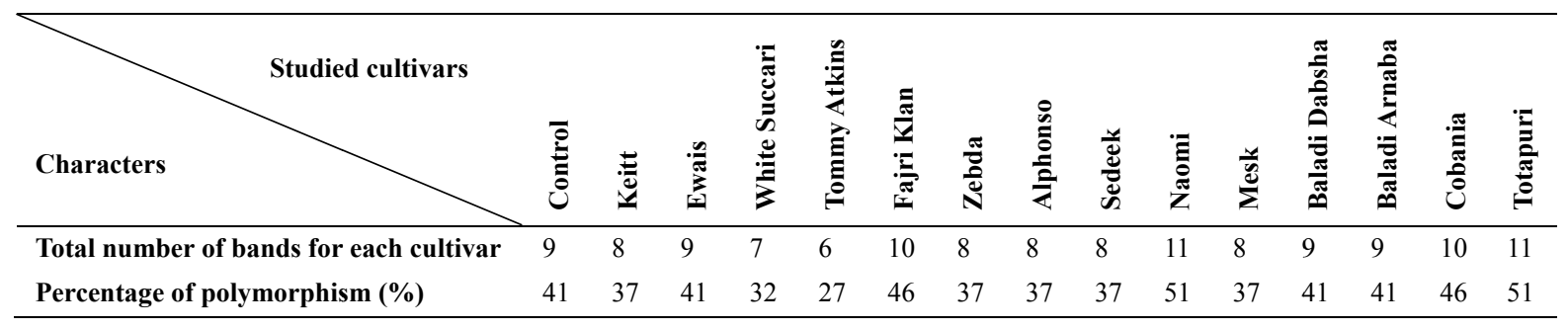


Table 3. Changes of both total and polymorphic bands in Hibiscus esculentus L. affected by $8 \%$ concentration of fourteen cultivars of Mangifera indica leaves aqueous extract; $a$, indicates appearance of new bands; $b$, indicates disappearance of normal bands; $c$, decrease in band intensities; $d$, increase in band intensities; $a+b$, denotes polymorphic bands; $a+b+c+d$, varied band and GTS\%, Genomic template stability

\begin{tabular}{llllllll}
\hline \multirow{2}{*}{ Studied cultivars } & \multicolumn{7}{c}{ Bands } \\
\cline { 2 - 6 } & $\mathbf{a}$ & $\mathbf{b}$ & $\mathbf{c}$ & $\mathbf{d}$ & $\mathbf{a}+\mathbf{b}$ & $\mathbf{a}+\mathbf{b}+\mathbf{c}+\mathbf{d}$ & \\
\hline Control & 0 & 0 & 0 & 0 & 0 & 0 & $100 \%$ \\
Keitt & 5 & 6 & 2 & 1 & 11 & 14 & $50 \%$ \\
Ewais & 6 & 6 & 2 & 1 & 12 & 15 & $46 \%$ \\
White Succari & 6 & 7 & 2 & 0 & 13 & 15 & $41 \%$ \\
Tommy Atkins & 2 & 6 & 2 & 1 & 8 & 11 & $64 \%$ \\
Fajri Klan & 7 & 6 & 3 & 0 & 13 & 16 & $41 \%$ \\
Zebda & 4 & 6 & 3 & 0 & 10 & 13 & $55 \%$ \\
Alphonso & 5 & 6 & 3 & 0 & 11 & 14 & $50 \%$ \\
Sedeek & 5 & 6 & 2 & 1 & 11 & 14 & $50 \%$ \\
Naomi & 8 & 6 & 3 & 1 & 14 & 18 & $36 \%$ \\
Mesk & 5 & 6 & 3 & 0 & 11 & 14 & $50 \%$ \\
Baladi Dabsha & 7 & 7 & 2 & 0 & 14 & 16 & $36 \%$ \\
Baladi Arnaba & 4 & 5 & 2 & 1 & 9 & 12 & $59 \%$ \\
Cobania & 8 & 7 & 2 & 0 & 15 & 17 & $32 \%$ \\
Totapuri & 7 & 5 & 3 & 1 & 12 & 16 & $45 \%$ \\
\hline
\end{tabular}

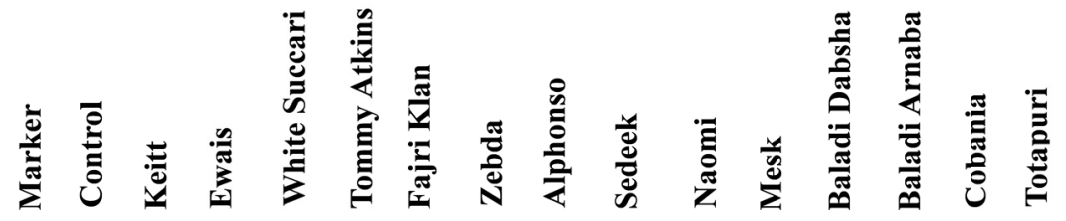

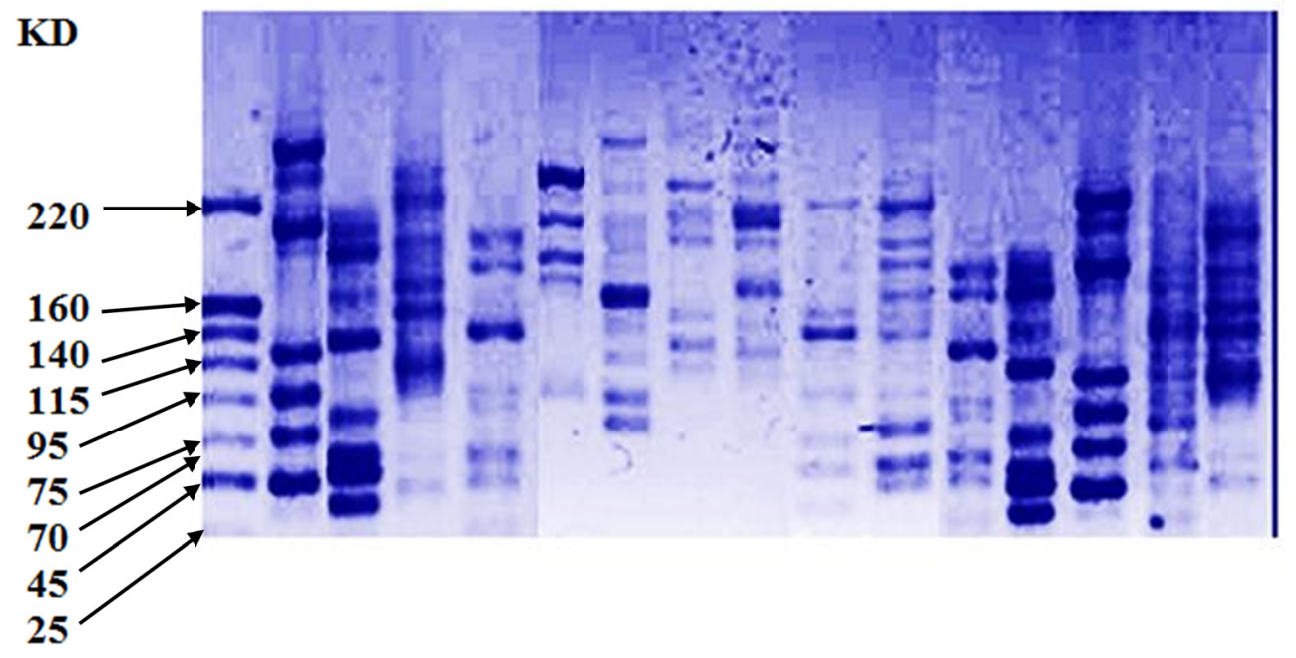

Figure 4. Seedling protein electrophoresis obtained from the leaves of Hibiscus esculentus L. affected by $8 \%$ concentration level of the fourteen cultivars of Mangifera indica L. leaves aqueous extract 


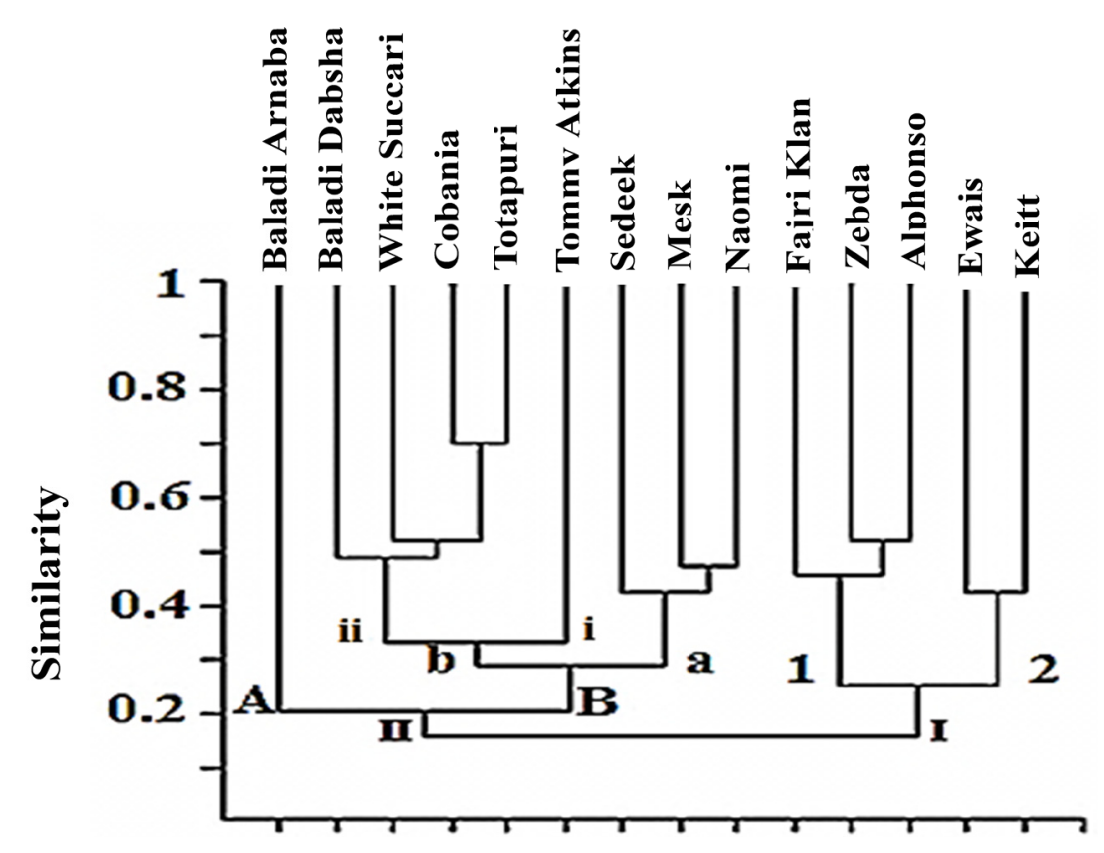

Figure 5. Dendrogram resulting from UPGMA method of sorting using the seedling protein electrophoresis obtained from the leaves of Hibiscus esculentus affected by $8 \%$ concentration level of the fourteen cultivars of Mangifera indica $\mathrm{L}$. leaves aqueous extract

\section{Discussion}

In the present study, the allelopathic potential of fourteen cultivars of $M$. indica leaves aqueous extracts (MILAE) under different concentrations levels $(1,2,4$ and $8 \%$ compare to control) on germination (GP) and (EP) of $H$. esculentus L. was confirmed (as a recipient species). Data suggested that the GP and EP of $H$. esculentus seeds was differentially affected by MILAE and the reduction was concentration dependent, these assessments are in a harmony with Sazada et al. (2009), Sahoo et al. (2010), Aamir and Ibrahim (2013), Khan et al. (2013), and Ma et al. (2014). Reduction in GP and EP, also may be due to different allelochemicals present in MILAE such as mangiferin, saponin, steroids, tannin, flavonoid, reducing sugars, cardiac glycosides and different phenolics (Aiyelaagbe \& Osamudiamen, 2009; Luo et al., 2012; El-Darier et al., 2015). These compounds have been reported to be active allelopathic chemicals effect on GP and EP (El-Rokiek et al., 2011; Algandaby et al., 2014), where phenolic compounds inhibit the activity of GA or inhibit the synthesis of GA which regulate de novo amylase production during seed germination (Chandler et al., 1984; Einhellig, 1996). Inhibition percentage (IP) of GP and EP in the H. esculentus increased gradually with the increase of MILAE concentration levels. These results agree with Abou-Zeid and El-Darier (2014) and El-Darier et al. (2014). Alam and Islam (2002) and Amoo et al. (2008) suggested that the inhibition percentage (IP) of crop plants may be due to the disturbance in many physiological processes in receptor plants as well as activities of peroxidase, alpha-amylase and acid phosphates, which resulting in a reduction of plant growth and development with subsequent yield reduction.

A gradual increase in the mean emergence time (MET) of the recipient species as a response to the regular applying of higher MILAE concentration levels was attained. At the full-strength concentration (8\%) Mesk cultivar exerts the highest allelopathic effect on MET of $H$. esculentus. This result is in agreement with Abdul Khaliq et al. (2012). The highest MET increases when the aqueous extract of MILAE concentration increased which showed that increased MILAE concentration caused a decrease in germination velocity (Modhej et al., 2013; Noghondar \& Azizi, 2013). Results of seed germination seedling vigour (SVI) index indicated that a gradual reduction of all germination indices in the recipient species as a response to the regular applying of higher MILAE concentration levels was attained. At the full-strength concentration (8\%) Mesk cultivar exerts the highest allelopathic effect on the SVI of H. esculentus seeds. SVI assessments are in a harmony with Tanveer et al. (2010) and Ali et al. (2012), they found a gradual reduction in SVI Triticum aestivum, Cicer arietinum, and Lens culinaris relative to mungbean as a response to the higher concentration levels of Euphorbia helioscopia and Rhynchosia capitata aqueous extract respectively. 
The current study inferred that the hypocotyl length (HL) of $H$. esculentus was found more sensitive and responds more strongly to the increase in MILAE concentration than the radicle length (RL). These results are in concordance with El-Rokiek et al. (2010), Khan et al. (2013), Algandaby et al. (2014), and El-Darier et al. (2014). On contrary, Turk and Tawaha (2002, 2003), Ashrafi et al. (2008), and El-Darier and Zein El-Dien (2011) reported that water extracts of allelopathic plants had more pronounced effects on radicle than on hypocotyl growth. The reduction in both radicle length and hypocotyl length may be due to phytotoxic activity of phytochemicals present in aqueous extracts of $M$. indica leaves like mangiferin, saponin, steroids, tannin, flavonoid, reducing sugars and cardiac glycosides (Jutiviboonsuk \& Sardsaengjun, 2010; Bhuvaneswari, 2013). It also contains phenolics like polyphenols, ferulic, cumaric acid, benzoic, vanelic, chlorogenic, caffeic, gallic, hydroxybenzoic, phenylpropanoids, mangiferin, mangin and cinnamon, These phenolic compounds have interfered with the phosphorylation pathway or inhibiting the activation of $\mathrm{Mg}^{2+}$ and ATPase activity or might be due to decreased synthesis of total carbohydrates, proteins and nucleic acids (DNA and RNA) or interference in cell division, mineral uptake and biosynthetic processes (El-Rokiek et al., 2010; Silva et al., 2012; El-Darier et al., 2015).

Results of both seedling fresh (SFW) and dry (SDW) weights indicated that a gradual reduction of (SFW) and dry (SDW) weights in the recipient species as a response to the regular applying of higher MILAE concentration levels was attained. At the full-strength concentration (8\%) Mesk cultivar exerts the highest allelopathic effect on the (SFW) and dry (SDW) weights of $H$. esculentus seeds; these results are in concordance with those reported by Barkatullah et al. (2010) and Pirzad et al. (2010).

\subsection{Seedling Protein Electrophoresis}

In the present study the potential of seedling storage protein to assess the genetic diversity among the fourteen $H$. esculentus seedling affected by $8 \%$ M. indica leaves aqueous extract (MILAE) of the fourteen cultivars. This electrophoretic technique is commonly used onto taxa that are phenotypically closely related (Galani et al., 2011), specifies as a beneficial method for discrimination of several genotypes (Agafonov et al., 2001) and characterization among cultivars (Rao et al., 2013; Dar et al., 2014). It is obvious through the estimation of the genomic template stability percentage, which are relatively low in comparison with the control. This is in concordance with El-Khawas and Shehata (2005) and Hegazy et al. (2007) that the seedling proteins decrease with the increasement in the concentration of allelochemicals. This reduction may be due to the presence of phenolic compounds, which reduce the incorporation of phosphorus into DNA and RNA. Meanwhile, Baziramakenga et al. (1997) and Padhy et al. (2000) concluded that phenolic acids reduced the incorporation of certain amino acid into proteins and thus reduce the rate of protein synthesis. Allelochemicals significantly interfered with the protein expression of the recipient species (H. esculentus). These allelochemicals could play an important role in inhibiting enzymes involved in these two processes accordance with Baziramakenga et al. (1997) who pointed out that the methionine incorporation into proteins was reduced by allelochemicals. Furthermore, it is notable the intensity of protein bands decrease or increase depended on type of allelochemicals found in the fourteen mango cultivars, which affected on the recipient species (H. esculentus) (El-Khawas \& Shehata, 2005; Sunar et al., 2013; Yumnamcha et al., 2014 ).

\section{Conclusion}

The present study was accomplished to study the effect of fourteen cultivars (Keitt, Ewais, White Succari, Tommy Atkins, Fajri Klan, Zebda, Alphonso, Sedeek, Naomi, Mesk, Baladi Dabsha, Baladi Arnaba, Cobania and Totapuri) of Mangifera indica L. leaves aqueous extracts (MILAE) on germination and some growth parameters as well as seedling protein profile of Hibiscus esculentus L. (okra seeds) in mixed cropping system. The study was extented to characterize and discriminate among the above-mentioned cultivars. This study recommends multiples cropping system by planting okra beside Totapuri mango cultivar depending on allelopathic, seedling protein electrophoresis data, that return to the low allelopathic effect of Totapuri cultivar due to absence of many phytochemicals such as alkaloids, flavonoids, saponins, steroids, tannins, phenolics, glycosides, triterpenoids, amino acids, carbohydrates and reducing sugar, also recorded low amount of quercetin, mangiferin and tannins. Okra seedling affected by Totapuri cultivar exerted high percentage of genome template stability (GTS \%) of about $45 \%$, while avoid planting okra seeds beside Mesk cultivar because this cultivar exert the highest allelopathic effect due to presence of mamy effective phytochemicals. Also, the resulted dendrogram depended on allelopathic data and the other dendogram subject to seedling protein elecrtrophoresis data ascertains three aggregations. The first assembly includes Sedeek, Naomi and Mesk cultivars. The second gathers Keitt and Ewais cultivars. While, the third clusters Fajri Klan, Zebda and Alphonso cultivars. 


\section{References}

Aamir, A., \& Ibrahim, S. (2013). FYM+NPK fertilization to control allellochemical effects of Mangifera indica L. leaf leachate on Lens culinaris L. Journal of Physics and Chemistry of Solids, 6, 21-25.

Abdul Khaliq, A., Matloob, A., Tanveer, A., Abbas, N. R., \& Khan, M. B. (2012). Bio-herbicidal properties of sorghum and sunflower aqueous extracts against germination and seedling growth of dragon spurge (Euphorbia dracunculoides Lam.). Pakistan Journal of Weed Science Research, 18(2), 137-148.

Abourayya, M. S., Kassim, N. E., El-Sheikh, M. H., \& Rakha, A. M. (2012). Evaluation of vegetative growth of Tomy Atkins, Kent and Keitt mango cultivars grown under Nubariya conditions. Journal of Applied Sciences Research, 8(2), 887-895.

Abou-Zeid, H. M., \& El-Darier, S. M. (2014). Biological interactions between Moringa oleifera Lam. and two common food intercrops: Growth and some physiological attributes. International Journal of Advanced Research, 2(6), 823-836.

Agafonov, A. V., Struzhkina, O. A., \& Baturin, S. O. (2001). SDS-PAGE of endosperm proteins of individual seeds of Poa pratensis L. (Poaceae) in ecological and genetic studies. Sibirskii Ekologicheskii Zhurnal, 31(1), $36-41$.

Aiyelaagbe, O. O., \& Osamudiamen, P. M. (2009). Phytochemical screening for active compounds in Mangifera indica leaves from Ibadan, Oyo State. Plant Sciences Research, 2(1), 11-13.

Alam, S. M., \& Islam, E. U. (2002). Effect of aqueous extract of leaf, stem and root of nettle leaf goosefoot and $\mathrm{NaCl}$ on germination and seedling growth of rice. Pakistan Journal of Biological Sciences, 1(2), 47-52.

Algandaby, M. M., El-Kenany, E. T., \& El-Darier, S. M. (2014). Management of Chenopodium album L. through the allelopathic Effect of Mangifera indica L. Journal of Life Sciences, 8(3), 230-237.

Ali, H. H., Tanveer, A. A., Nadeem, M. A., Javaid, M. M., Kashif, M. S., \& Chadhar, A. R. (2012). Allelopathic effects of Rhynchosia Capitata on germination and seedling growth of mungbean. Planta Daninha, Viçosa-MĢ, 31(3), 501-509. https://doi.org/10.1590/S0100-83582013000300002

Amoo, S. O., Ojo, A. U., \& Staden, J. V. (2008). Allelopathic potential of Tetrapleura tetraptera leaf extracts on early seedling growth of five agricultural crops. South African Journal of Botany, 74, 149-152. https://doi.org/10.1016/j.sajb.2007.08.010

Ashrafi, Z. Y., Sadeghi, S., Mashhadi, H. R., \& Hassan, M. A. (2008). Allelopathic effects of Sunflower (Helianthus annuus) on germination and growth of Wild Barley (Hordeum spontaneum). Journal of Agricultural Science and Technology, 4, 219-229.

Association of Official Seed Analysts (AOSA). (1990). Rules for testing seeds. Journal of Seed Science and Technology, 12, 1-112.

Bally, I. S. (2006). Mangifera indica, Anacardiaceae (cashew family). In C. R. Elevitch (Ed.), Species profiles for Pacific Island Agroforestry (p. 25). Permanent Agriculture Resources, Hōlualoa, Hawaii.

Barkatullah, A., Hussain, F., \& Ibrar, M. (2010). Allelopathic potential of Dodonaea viscosa (L.) Jacq. Pakistan Journal of Botany, 42(4), 2383-2390.

Baziramakenga, R., Leroux, G., Simard, R., \& Nadeau, P. (1997). Allelopathic effects of phenolic acids on nucleic acids and protein levels in soybean seedlings. Canadian Journal of Botany, 75, 445-450. https://doi.org/10.1139/b97-047

Bertholdsson, N. (2012). Allelopathy-a tool to improve the weed competitive ability of wheat with herbicide-resistant Black-grass (Alopecurus myosuroides Huds.). Agronomy, 2, 284-294. https://doi.org/ 10.3390/agronomy2040284

Bhuvaneswari, K. (2013). Isolation of mangiferin from leaves of Mangifera indica L. Var Alphonso. Asian Journal of Pharmaceutical and Clinical Research, 6(2), 173-174.

Cenkci, S., Ciĝerci, I., Yildiz, M., Özay, C., Bozdậ, A., \& Terzi, H. (2010). Lead contamination reduces chlorophyll biosynthesis and genomic template stability in Brassica rapa L. Environmental and Experimental Botany, 67, 467-473. https://doi.org/10.1016/j.envexpbot.2009.10.001

Chandler, P. M., Zucar, J. A., Jacobson, J. V., Higgins, T. J., \& Inglis, A. S. (1984). The effect of gibberellic acid and abscisic acid on a-amylase mRNA levels in barley aleurone layers studies an amylase cDNA clone. Plant Molecular Biology, 3, 407-408. https://doi.org/10.1007/BF00033389 
Cheema, Z., Farooq, M., \& Abdul Wahid, A. (2013). Allelopathy: Current Trends and Future Application (p. 520). Springer-Verlag, Berlin, Heidelberg. https://doi.org/10.1007/978-3-642-30595-5

Cimino, M. C. (2006). Comparative overview of current international strategies and guidelines for genetic toxicology testing for regulatory purposes. Environmental Molecular Mutagenesis Journal, 47, $362-390$. https://doi.org/10.1002/em.20216

Dar, A. A., Choudhury, A. R., \& Arumugam, N. A. (2014). A study on seed protein profile of Indian cultivars of Sesamum indicum L. International Journal of Biotechnology, 2(6), 10-17.

Einhellig, F. A. (1996). Mechanism of action of allelochemicals in allelopathy. Agronomy Journal, 88, 886-893. https://doi.org/10.2134/agronj1996.00021962003600060007x

El-Darier, S. M., \& Zein El-Dien, M. H. (2011). Biological activity of Medicago sativa L. (alfalfa) residues on germination efficiency, growth and nutrient uptake of Lycopersicon esculentum L. (tomato) seedlings. Journal of Taibah University for Science, 5, 7-13. https://doi.org/10.1016/S1658-3655(12)60033-8

El-Darier, S. M., Marzouk, R. I., \& Khattab, K. A. (2014). Differential allelopathic effect of nine Haplophyllum tuberculatum growth forms through germination bioassay. Journal of Biodiversity and Environmental Sciences, 5(5), 1-11.

El-Darier, S. M., Marzouk, R. I., Mabrouk, M. E., \& Khattab, K. A. (2015). Phytochemical differentiation among fourteen cultivars of mango (Mangifera indica L.) leaves from Al-Sharqia, Egypt. CATRINA, 12(1), 87-93.

El-Kenany, E. T., El-Darier, S. M., Kamal, S. A., \& Belgassem, N. (2014). The probable allelopathic interference of Nigella sativa L. seed extracts with Lupinus termis L. CATRINA, 10(1), 9-18.

El-Khawas, S. A., \& Shehata, M. M. (2005). The Allelopathic Potentialities of Acacia nilotica and Eucalyptus rostrata on Monocot (Zea mays L.) and Dicot (Phaseolus vulgaris L.) Plants. Biotechnology, 4(1), 23-34.

Ellis, R. A., \& Roberts, E. H. (1981). The quantification of ageing and survival in orthodox seeds. Seed Science and Technology, 9, 373-409.

Elouaer, M. A., \& Hannachi, C. (2012). Seed priming to improve germination and seedling growth of safflower (Carthamus tinctorius) under salt stress. EurAsian Journal of BioSciences, 6, 76-84. https://doi.org/10.5053/ ejobios.2012.6.0.9

El-Rokiek, G. K., El-Masry, R. R., Messiha, K. N., \& Ahmed, S. A. (2010). Allelopathic effect of mango Leaves on the growth and propagative capacity of purple nutsedge (Cyperus rotundus L.). Journal of American Science, 6(9), 151-159.

El-Rokiek, K. G., Messiha, N. K., El-Masry, R. R., \& Saad El-Din, S. A. (2011). Evaluating the Leaf Residues of Eucalyptus globulus and Mangifera indica on Growth of Cynodon dactylon and Echinochloa colonum. Journal of Applied Sciences Research, 7(12), 1793-1799.

Galani, S., Naz, F., Soomro, F., Jamil, I., Hassan, Z., Azhar, A., \& Ashraf, A. (2011). Seed storage protein polymorphism in ten elite rice (Oryza sativa L.) genotypes of Sindh. African Journal of Biotechnology, 10(7), 1106-1111.

Ghafoor, A., Ahmad, Z., Qureshi, A. S., \& Bashir, M. (2002). Genetic relationship in Vigna mungo (L.) Hepper and $V$. radiata (L.) R. Wilczek based on morphological traits and SDS-PAGE. Euphytica, 123, 367-378. https://doi.org/10.1023/A:1015092502466

Hammer, Ø. A., Harper, D. A., \& Ryan, P. D. (2001). Paleontological statistics software package for educational and data analysis. Palaeontologia Electronica, 4(1), 4-9.

Hammer, Ø. A., Harper, D. A., \& Ryan, P. D. (2005). PAST-Palaeontological Statistics (Version 1.34).

Hegazy, A. K., Goda, S. K., \& Farrag, H. F. (2007). Protein Expressions of Some Cultivated and Weed Plants in Response to Invasive Plant Mulching. Global Journal of Molecular Sciences, 2(1), 01-07.

Iqbal, S. H., Ghafoor, A., \& Ayub, N. (2005). Relationship between SDS-PAGE markers and Ascochyta blight in chickpea. Pakistan Journal of Botany, 37, 87-96.

Isemura, T., Shiyo, N., \& Shigeyuki, M. (2001). Genetic variation and geographical distribution of Azuki bean (Vigna angularis) landraces based on the electrophoregram of seed storage proteins. Breeding Science, 51, 225-230. https://doi.org/10.1270/jsbbs.51.225 
Islam, A. K., Anuar, N., \& Yaakob, Z. (2009). Effect of genotypes and pre-sowing treatments on seed germination behavior of Jatropha. Asian Journal of Plant Science, 8, 433-439. https://oi.org/10.3923/ ajps.2009.433.439

Javid, A., Ghafoor, A., \& Anwar, R. (2004). Seed storage protein electrophoresis in groundnut for evaluating genetic diversity. Pakistan Journal of Botany, 36(1), 25-29.

Jutiviboonsuk, A., \& Sardsaengjun, C. (2010). Mangiferin in leaves of three Thai mango (Mangifera indica L.) varieties. Indian Journal of Pharmaceutical Sciences, 6(3), 122-129.

Khan, M. S., Islam, M. A., \& Noguchi, H. K. (2013). Evaluation of allelopathic activity of three mango (Mangifera indica) cultivars. Asian Journal of Plant Sciences, 12(6-8), 252-261.

Kumar, M., Ponnuswami, V., Nagarajan, P., Jeyakumar, P., \& Senthil, N. (2013). Molecular characterization of ten mango cultivars using simple sequences repeat (SSR) markers. African Journal of Biotechnology, 12(47), 6568-6573. https://doi.org/10.5897/AJB2013.12797

Labbafi, M. R., Hejazi, A., Maighany, F., Khalaj, H., \& Mehrafarin, A. (2010). Evaluation of allelopathic potential of Iranian wheat (Triticum aestivum L.) cultivars against weeds. Agriculture and Biology Journal of North America, 1(3), 355-361. https://doi.org/10.5251/abjna.2010.1.3.355.361

Laemmli, U. K. (1970). Cleavage of structural proteins during the assembly of bacteriophage T4. Nature, 277, 680-684. https://doi.org/10.1038/227680a0

Luo, F., Lv, Q., Zhao, Y., Hu, G., Huang, G., Zhang, J., ... Chen, K. (2012). Quantification and purification of mangiferin from Chinese mango (Mangifera indica L.) cultivars and its protective effect on human umbilical vein endothelial cells under $\mathrm{H}_{2} \mathrm{O}_{2}$-induced stress. International Journal of Molecular Sciences, 13 , 11260-11274. https://doi.org/10.3390/ijms130911260

Ma, Y., Zhang, M., Li, Y., Shui, J., \& Zhou, Y. (2014). Allelopathy of rice (Oryza sativa L.) root exudates and its relations with Orobanche cumana Wallr. and Orobanche minor Sm. germination. Journal of Plant Interactions, 9(1), 722-730. https://doi.org/10.1080/17429145.2014.912358

Mansour, H., Mekki, L. E., \& Hussein, A. M. (2014). Assessment of genetic diversity and relationships among Egyptian mango (Mangifera indica L.) cultivers grown in Suez Canal and Sinai region using RAPD markers. Pakistan Journal of Biological Sciences, 17(1), 56-61. https://doi.org/10.3923/pjbs.2014.56.61

Modhej, A., Rafatjoo, A., \& Behdarvandi, B. (2013). Allelopathic inhibitory potential of some crop species (wheat, barley, canola, and safflower) and wild mustard (Sinapis arvensis). International Journal of Biosciences, 3(10), 212-220. https://doi.org/10.12692/ijb/3.10.212-220

Netra, N., \& Prasad, S. (2007). Identification of rice hybrids and their parental lines based on seed, seedling characters, chemical tests and gel electrophoresis of total soluble seed proteins. Seed Science and Technology, 35, 176-186. https://doi.org/10.15258/sst.2007.35.1.16

Niakan, M., Tajari, M., \& Ghorbanli, M. (2008). Effects of salinity on allelopathic potential of canola (Brassica napus L.). Allelopathy Journal, 21, 329-338.

Noghondar, M., \& Azizi, M. (2013). Seed harvesting time affects seedling emergence, vigour and growth: case study of Rumex turcomanicus Czerep. (Polygonaceae). Notulae Scientia Biologicae, 5(2), 244-248.

Padhy, B. B., Patanaik, P. K., \& Tripathy, A. K. (2000). Allelopathic potential of Eucalyptus leaf lifter leachates on germination and seedling growth of fingermillet. Allelopathy Journal, 7, 69-78.

Pirzad, A., Ghasemian, V., Darvishzadeh, R., Sedghi, M., Hassani, A., \& Onofri, A. (2010). Allelopathy of Sage and White Wormwood on Purslane Germination and Seedling Growth. Notulae Scientia Biologicae, 2(3), 91-95.

Putnam, A. R., \& Duke, W. B. (1978). Allelopathy in Agroecosystems. Annual Review of Phytopathology, 16, 431-451. https://doi.org/10.1146/annurev.py.16.090178.002243

Rao, P. S., Bharathi, M. A., \& Reddy, K. B. (2013). Identification of peanut (Arachis hypogaea L.) varieties through chemical tests and electrophoresis of soluble seed proteins. Legume Research, 36(6), 475-483.

Reigosa, J., Pedrol, N., \& González, L. (2006). Allelopathy: A Physiological Process with Ecological Implications (p. 639). Springer. https://doi.org/10.1007/1-4020-4280-9

Rice, E. L. (1974). Allelopathy (p. 353). Academic Press, New York. 
Sadia, M. A., Malik, S. A., Rabbani, M. A., \& Peaece, S. R. (2009). Electrphoretic characterization and the relationship between some brassica species. Electronic Journal of Biology, 5, 1-4.

Sahoo, U. K., Jeeceelee, L., Vanlalhriatpuia, K., Upadhyaya, K., \& Lalremruati, J. H. (2010). Allelopathic effects of leaf leachate of Mangifera indica $\mathrm{L}$. on initial growth parameters of few homegarden food crops. World Applied Sciences Journal, 10(12), 1438-1447.

Sammour, R. H. (1991). Using electrophoretic techniques in varietal identification, biosystematic analysis, phylogenetic relations and genetic resources management. Medical Journal of Islamic World Academy of Sciences, 4, 221-226.

Sazada, S., Khan, S. S., Meghvanshi, M. K., \& Bhardwaj, S. (2009). Allelopathy effects of aqueous extract of Acacia nilotica on seed germination and radical length of Triticum aestivum var. Lok-1. Indian Journal of Applied and Pure Biology, 24(1), 271-220.

Silva, R. R., Câmara, C. A., Almeidab, A. V., \& Ramos, C. S. (2012). Biotic and Abiotic Stress-Induced Phenylpropanoids in Leaves of the Mango (Mangifera indica L., Anacardiaceae). Journal of the Brazilian Chemical Society, 23(2), 206-211. https://doi.org/10.1590/s0103-50532012000200003

Sunar, S., Yildirim, N., Aksaka, O., \& Agar, G. (2013). Determination of the genotoxic effects of Convolvulus arvensis extracts on corn (Zea mays L.) seeds. Toxicology and Industrial Health, 29(5), 449-459. https://doi.org/10.1177/0748233712436644

Tanveer, A., Rehman, A., Javaid, M. M., Abbas, R. N., Sibtain, M., Ahmad, A., \& Aziz, A. (2010). Allelopathic potential of Euphorbia helioscopia L. against wheat (Triticum aestivum L.), chickpea (Cicer arietinum L.) and lentil (Lens culinaris Medic.). Turkish Journal of Agriculture and Forestry, 34, 75-81.

Turk, M. A., \& Tawaha, A. M. (2002). Inhibitory effects of aqueous extracts of black mustard on germination and growth of lentil. Pakistan Journal of Agronomy, 11, 28-30.

Turk, M. A., \& Tawaha, A. M. (2003). Allelopathic effect of black mustard (Brassica nigra L.) on germination and growth of wild oat (Avena fatua L.). Crop Protection, 22(4), 673-677. https://doi.org/10.1016/S0261-2194 (02)00241-7

Young, C. C., Thorne, L. R., \& Waller, G. R. (1989). Phytotoxic potential of soils and wheat straw in rice rotation cropping systems of subtropical Taiwan. Plant and Soil, 120, 95-101. https://doi.org/10.1007/BF02370295

Yumnamcha, T., Nongthomba, U., \& Devi, M. D. (2014). Phytochemical screening and evaluation of genotoxicity and acute toxicity of aqueous extract of Croton tiglium L. International Journal of Scientific and Research Publications, 4(1), 1-5.

Zar, J. H. (1984). Biostatistical Analysis (p. 718). Prentice-Hall: Inc. New Jersey.

\section{Copyrights}

Copyright for this article is retained by the author(s), with first publication rights granted to the journal.

This is an open-access article distributed under the terms and conditions of the Creative Commons Attribution license (http://creativecommons.org/licenses/by/4.0/). 